\title{
Correction to: Growth response of Betula pubescens Ehrh. to varying disturbance factors in northern Norway
}

\author{
Lorenz Harr $^{1}$ [ $\cdot$ Jan Esper ${ }^{1} \cdot$ J. Andreas Kirchhefer ${ }^{2} \cdot$ Wang Zhou $^{1,3,4,5,6} \cdot$ Claudia Hartl $^{1}$
}

Published online: 7 September 2021

(c) The Author(s) 2021

\section{Correction to: Trees (2021) 35:421-431 https://doi.org/10.1007/s00468-020-02043-1}

The article "Growth response of Betula pubescens Ehrh. To varying disturbance factors in northern Norway", written by Lorenz Harr, Jan Esper, J. Andreas Kirchhefer, Wang Zhou, and Claudia Hartl, was originally published Online First without Open Access. After publication in volume 35, issue 2, page 421-431 the author decided to opt for Open Choice and to make the article an Open Access publication. Therefore, the copyright of the article has been changed to ()$^{\circ}$ The Author(s) 2021 and the article is forthwith distributed under the terms of the Creative Commons Attribution 4.0 International License, which permits use, sharing, adaptation, distribution and reproduction in any medium or format, as long as you give appropriate credit to the original author(s) and the source, provide a link to the Creative Commons licence,

The original article can be found online at https://doi.org/10.1007/ s00468-020-02043-1.

\section{Lorenz Harr}

L.Harr@geo.uni-mainz.de

1 Department of Geography, Johannes Gutenberg-University, Johann-Joachim-Becher-Weg 21, 55128 Mainz, Germany

2 Dendroøkologen, Skogåsvegen 6, 9011 Tromsö, Norway

3 Key Laboratory of Vegetation Restoration and Management of Degraded Ecosystems, South China Botanical Garden, Chinese Academy of Sciences, 723 Xingke Road, Tianhe District, Guangzhou 510650, China

4 Center of Plant Ecology, Core Botanical Gardens, Chinese Academy of Sciences, 723 Xingke Road, Tianhe District, Guangzhou 510650, China

5 Guangdong Provincial Key Laboratory of Applied Botany, South China Botanical Garden, Chinese Academy of Sciences, 723 Xingke Road, Tianhe District, Guangzhou 510650, China

6 University of Chinese Academy of Sciences, 19A Yuquanlu, Beijing 100049, China and indicate if changes were made. The images or other third party material in this article are included in the article's Creative Commons licence, unless indicated otherwise in a credit line to the material. If material is not included in the article's Creative Commons licence and your intended use is not permitted by statutory regulation or exceeds the permitted use, you will need to obtain permission directly from the copyright holder. To view a copy of this licence, visit http:// creativecommons.org/licenses/by/4.0. Open access funding enabled and organized by Projekt DEAL.

The original article has been corrected.

Open Access This article is licensed under a Creative Commons Attribution 4.0 International License, which permits use, sharing, adaptation, distribution and reproduction in any medium or format, as long as you give appropriate credit to the original author(s) and the source, provide a link to the Creative Commons licence, and indicate if changes were made. The images or other third party material in this article are included in the article's Creative Commons licence, unless indicated otherwise in a credit line to the material. If material is not included in the article's Creative Commons licence and your intended use is not permitted by statutory regulation or exceeds the permitted use, you will need to obtain permission directly from the copyright holder. To view a copy of this licence, visit http://creativecommons.org/licenses/by/4.0/.

Publisher's Note Springer Nature remains neutral with regard to jurisdictional claims in published maps and institutional affiliations. 